\title{
The Right to Asylum and the Principle of Non- Refoulement Under the European Convention on Human Rights
}

\author{
Jelena Ristik, PhD \\ Assistant Professor School of Law, \\ University American College Skopje, Republic of Macedonia
}

Doi: 10.19044/esj.2017.v13n28p108 URL:http://dx.doi.org/10.19044/esj.2017.v13n28p108

\begin{abstract}
The European Convention on Human Rights does not contain any explicit reference to the right to asylum. However, the European Court of Human Rights has provided protection of asylum seekers mainly through interpretation of Article 3 of the Convention. Moreover, even if there is no specific mention of non-refoulement in this Article, the Court has interpreted it to include the prohibition of refoulement. Today, the ECHR is one of the most important juridical instruments for protection of asylum seekers throughout Europe. The main reason for this is that the principle of nonrefoulement under the Convention extends to inhuman and degrading behavior. This paper has placed its focus on the applicability of the ECHR to asylum cases, particularly the development and treatment of the principle of non-refoulement, as a form of complementary protection to those seeking asylum. This will be elaborated mainly through analysis of the jurisprudence of the ECtHR. It will be shown that the principle of non-refoulement under the ECHR, as a barrier to removal, plays a significant complementary role regarding the protection of asylum seekers. It will also be shown that the jurisprudence of the ECtHR has important relevance to EU asylum law and policy. In this sense, a comparison between EU law and ECHR protection standards for asylum seekers will be elaborated as well. Finally, it will be concluded that EU Member States are faced with dual systems providing protection to asylum seekers, and a possible solution will be suggested in order to overcome this situation.
\end{abstract}

Keywords: Right to asylum, principle of non-refoulement, European Convention on Human Rights, European Court of Human Rights, EU Law 


\section{Introduction}

The right of states to admit or exclude aliens of their territory is one of the main features of the concept of national sovereignty. States are bound to admit aliens only in cases where exclusion from the territory or from protection would constitute a breach of certain international law provision. The most significant example of the latter principle is the right to asylum (Mole and Meredith, 2010: 10).

There are several main legal regimes for the international protection of asylum seekers and refugees in Europe: the 1951 United Nations Convention relating to the Status of Refugees ("Refugee Convention") and its 1967 Protocol; the law of the European Union ("EU law"); the 1984 United Nations Convention against Torture and other Cruel, Inhuman or Degrading Treatment or Punishment ("UNCAT") and the 1950 Convention for the Protection of Human Rights and Fundamental Freedoms, or better known as the European Convention on Human Rights ("ECHR") and its Protocols. These legal regimes exist simultaneously and they often overlap (Mole and Meredith, 2010: 7). Nonetheless, it could be claimed that the Refugee Convention, together with its 1967 Protocol, is "the starting point for considering asylum in Europe" (European Union Agency for Fundamental Rights and Council of Europe, 2014: 64)

However, it should be noted that the percentage of individuals whose situation falls outside the ambit of the Refugee Convention, the UNCAT and the EU law is rather high (Maas, 2009: 5; Mole and Meredith, 2010: 8). On the other hand, these individuals are granted protection under the ECHR (Mole and Meredith, 2010: 8), despite the fact that the ECHR does not contain any explicit reference to the right to asylum, or any specific mention of non-refoulement (Bacian, 2011: 40; 53-54).

Namely, the European Court of Human Rights ("ECtHR) has provided protection of asylum seekers mainly through interpretation of Article 3 of the ECHR. Moreover, even if there is no specific mention of non-refoulement in this Article, ECtHR has interpreted Article 3 to include the prohibition of refoulement (Bacian, 2011: 40, 53-54),

This paper has placed its focus on the applicability of the ECHR to asylum cases, particularly the development and treatment of the principle of non-refoulement, as a form of complementary protection to those seeking asylum. This will be elaborated mainly through analysis of the jurisprudence of the ECtHR. It will be shown that the principle of non-refoulement under the ECHR, as a barrier to removal, plays a significant complementary role regarding the protection of asylum seekers. It will also be shown that the jurisprudence of the ECtHR has important relevance to the EU asylum law and policy. In this sense, a comparison between EU law and ECHR protection standards for asylum seekers will be elaborated as well. Finally, it 
will be concluded that EU Member States are faced with dual systems providing protection to asylum seekers, and a possible solution will be suggested in order to overcome this situation.

\section{International Protection of Asylum Seekers and Refugees in Europe}

The Universal Declaration of Human Rights ("UDHR"), which is "considered to be the single most authoritative source of human rights norms" (Chapman, 1999: 133), provides protection of the right to "seek and enjoy asylum from persecution" within its Article 14. However, this right is not foreseen within the other general instruments for international human rights protection, such as the International Covenant on Civil and Political Rights ("ICCPR") or the ECHR. In large part, the latter is due to the fact that at the time when these human rights instruments were drafted, it was considered that the Refugee Convention would have the capacity to fully cover the need for protection of the right to asylum (Mole and Meredith, 2010: 10).

Indeed, in the early years of the Refugee Convention, there were no problems regarding the recognition as a refugee in Europe. However, this is not the case anymore. Namely, in the last couple of decades, European states have been demonstrating a relatively high level of reluctance to recognizing people in need of protection as refugees. Moreover, it could be noted that the role of the Refugee Convention "is now in many respects performed in the European context by general human rights instruments and, in particular, by the ECHR" (Mole and Meredith, 2010: 10-11).

The definition of a refugee, foreseen in Article 1A(2) of the Refugee Convention, according to which a refugee is someone who "owing to wellfounded fear of being persecuted for reasons of race, religion, nationality, membership of a particular social group or political opinion, is outside the country of his nationality and is unable or owing to such a fear, unwilling to avail himself of the protection of that country; or who, not having a nationality and being outside of the country of his former habitual residence as a result of such events, is unable or, owing to such fear, is unwilling to return to it ...", is now well recognized in international law, as well as the principle of non-refoulement, established in Article 33(1) of the Refugee Convention, which states the following: "No Contracting State shall expel or return ('refouler') a refugee in any manner whatsoever to the frontiers of territories where his life or freedom would be threatened on account of his race, religion, nationality, membership of a particular social group or political opinion" (United Nations Convention relating to the Status of Refugees, 1951). However, it should be noted that the Refugee Convention was designed to "provide a legal status for those persons who found themselves outside their country of nationality or habitual residence and in 
fear of persecution as a consequence of events occurring in Europe before 1 January 1951"' (Mole and Meredith, 2010: 11).

On the other hand, although the main reason behind the creation of the ECHR was "to provide legal regional recognition of most of the rights set out in the UDHR and to provide international mechanisms to police their implementation, there is no provision that reflects Article 14 of the UDHR (Mole and Meredith, 2010: 11). Namely, the ECHR does not contain any explicit reference to the right to asylum, nor it contains specific mention of the principle of refoulement (Bacian, 2011: 53).

Although the Refugee Convention is still effective and very important, many individuals who are in need of international protection due to being "at risk of expulsion to situations where they would face serious harm such as torture or inhuman and degrading treatment or punishment, or whose expulsion would in itself constitute such treatment", fall outside its scope. The main reason for this is the lack of possibility to establish a link between the persecution feared and one of the five grounds that the Refugee Convention foresees (race, religion, nationality, membership of a particular social group or political opinion) (Mole and Meredith, 2010: 11). In fact, according to the European Council on Refugees and Exiles, the individuals who fall within one of the categories of the Refugee Convention are "the exception rather than the rule" (Röhl, 2005: 1).

However, bearing in mind that the Refugee Convention is "the lex specialis of asylum" and "the key international instrument for protecting those who fall within its scope" (Mole and Meredith, 2010: 9), it is now largely incorporated into EU law through the Directive 2011/95/EU on Standards for the Qualifications of Third-Country Nationals or Stateless Persons as Beneficiaries of International Protection, for a Uniform Status of Refugees or for Persons Eligible for Subsidiary Protection, and for the Content of the Protection Granted ("Qualification Directive 2011/95/EU") (European Union Agency for Fundamental Rights and Council of Europe, 2014: 64). The Qualification Directive 2011/95/EU repeals the Directive 2004/83/EC on Minimum Standards for the Qualification and Status of Third Country Nationals or Stateless Persons as Refugees or as Persons Who Otherwise Need International Protection and the Content of the Protection Granted ("Qualification Directive 2004/83/EC") (European Union Agency for Fundamental Rights and Council of Europe, 2014: 64; Bacaian, 2011: 48), as one of instruments that led to the formation of Common European Asylum System ("CEAS"), which aims to "harmonize and streamline legal standards relating to asylum in the Member States of the EU" (Maas, 2009: 3).

Yet, the most relevant provision regarding the protection against removal, Article 15 read in conjunction with Article 2, remains in its content 
the same in the recast Qualitative Directive 2011/95/EU. Namely, Article 15 foresees the conditions for qualification for subsidiary protection, which is applicable only to an individual "who does not qualify as a refugee". (Maas, 2009: 19; Qualification Directive 2011/95/EU).

\section{Applicability of the ECHR to Asylum Cases}

Although the ECHR does not contain a provision that explicitly refers to the right to asylum, the ECtHR has provided protection of asylum seekers mainly through the various interpretations of Article 3 of the ECHR (Bacian, 2011: 53-54), which prohibits torture and "inhuman or degrading treatment or punishment" (Convention for the Protection of Human Rights and Fundamental Freedoms, 1950). In fact, there is a substantial body of jurisprudence of the ECtHR, which "sets the standards for the rights of asylum seekers all across Europe" (Mole and Meredith, 2010: 11).

The ECtHR has stated in several occasions that the right to asylum, as such, does not exist in the ECHR or its Protocols (Vilvarajah and Others $v$. the United Kingdom; Salah Sheekh v. the Netherlands) (Mole and Meredith, 2010: 11). In this sense, in the case of Lilia, Julia and Eleonora Alimzhanova and Alexjs Lisikov v. Sweden, the ECtHR found that "the Convention does not guarantee a right to asylum or refugee status, but only prohibits the expulsion of persons to a country where they may be subjected to treatment contrary to Article 3".

The issue of applicability of the ECHR to asylum cases was considered in detail for the first time in the case of Soering v. the United Kingdom (1989). This case did not concern a political asylum, but extradition (Maas, 2009: 17; Mole and Meredith, 2010: 11). The applicant was a German national, who was detained in prison in England pending extradition to the United States of America to face charges of murder in the Commonwealth of Virginia (Soering v. the United Kingdom, q11). At that time, the average time between trial and execution in Virginia was six to eight years. The delays were known as the "death row phenomenon" (Soering v. the United Kingdom, ๆ56). The applicant alleged that the decision by the Secretary of State for the Home Department to surrender him to the authorities of the United States of America would, if implemented, give rise to a breach by the United Kingdom of Article 3 of the ECHR (Soering v. the United Kingdom, $\mid 80)$. The ECtHR noted that the alleged breach derives from the applicant's exposure to the so-called "death row phenomenon", while it described this phenomenon as "consisting in a combination of circumstances to which the applicant would be exposed if, after having been extradited to Virginia to face a capital murder charge, he were sentenced to death" (Soering v. the United Kingdom, $\mathbf{\uparrow} 81$ ). 
The ECtHR also confirmed the existence of other international instruments, which explicitly regulate the issue of sending individuals in a country where they will face a risk to be exposed at prohibited treatment. In this sense, the ECtHR specifically mentioned the Refugee Convention, the 1957 European Convention on Extradition and the UNCAT (Soering v. the United Kingdom, - 186). However, it found that the existence of these international instruments could not "absolve the Contracting Parties from responsibility under Article 3 for all and any foreseeable consequences of extradition suffered outside their jurisdiction" (Soering $v$. the United Kingdom, ๆ86).

Furthermore, the ECtHR noted that "the fact that a specialised treaty should spell out in detail a specific obligation attaching to the prohibition of torture does not mean that an essentially similar obligation is not already inherent in the general terms of Article 3 of the ECHR". According to the Court, "it would hardly be compatible with the underlying values of the Convention, that 'common heritage of political traditions, ideals, freedom and the rule of law' to which the Preamble refers, were a Contracting State knowingly to surrender a fugitive to another State where there were substantial grounds for believing that he would be in danger of being subjected to torture, however heinous the crime allegedly committed". For this reason, the ECtHR concluded that "extradition in such circumstances, while not explicitly referred to in the brief and general wording of Article 3, would plainly be contrary to the spirit and intendment of the Article, and in the Court's view this inherent obligation not to extradite also extends to cases in which the fugitive would be faced in the receiving State by a real risk of exposure to inhuman or degrading treatment or punishment proscribed by that Article" (Soering v. the United Kingdom, ๆ88).

As a result of the assessment of the applicability of Article 3 in cases of extradition, the ECtHR has summed up that "... [T] he decision by a Contracting State to extradite a fugitive may give rise to an issue under Article 3, and hence engage the responsibility of that State under the Convention, where substantial grounds have been shown for believing that the person concerned, if extradited, faces a real risk of being subjected to torture or to inhuman or degrading treatment or punishment in the requesting country. The establishment of such responsibility inevitably involves an assessment of conditions in the requesting country against the standards of Article 3 ... [I]t is liability incurred by the extraditing Contracting State by reason of its having taken action which has as a direct consequence the exposure of an individual to proscribed ill-treatment" (Soering $v$. the United Kingdom, $\mathbf{9 9 1 ) .}$

Another important case as regards the applicability of the ECHR to asylum cases is the case of Cruz Varas v. Sweden. Namely, this case 
concerned a refused asylum seeker for the first time (Maas, 2009: 17; Mole and Meredith, 2010: 21). In this case, the ECtHR concluded that the principle established in the case of Soering $v$. the United Kingdom can also be applied to decisions to expel: "Although the present case concerns expulsion as opposed to a decision to extradite, the Court considers that the above principle also applies to expulsion decisions and a fortiori to cases of actual expulsion" (Cruz Varas v. Sweden, 970). This finding of the ECtHR was reiterated in the case of Vilvarajah and Others $v$. the United Kingdom (Mole and Meredith, 2010: 21). Namely, in this case, the Court has reaffirmed that "expulsion by a Contracting State of an asylum seeker may give rise to an issue under Article 3, and hence engage the responsibility of that State under the Convention, where substantial grounds have been shown for believing that the person concerned faced a real risk of being subjected to torture or to inhuman or degrading treatment or punishment in the country to which he was returned ..." (Vilvarajah and Others v. the United Kingdom, \103).

The ECtHR has most frequently considered asylum cases under Article 3. However, it should be mentioned that there are also other provisions within the ECHR, which are relevant to asylum issues. Namely, asylum cases may also rise issues of return to face risks under Article 2 (right to life), Article 4 (prohibition of slavery, servitude and compulsory labor), Article 5 (right to liberty and security), Article 6 (right to a fair trial), Article 7 (prohibition on retroactive criminal punishment), Article 8 (right to respect for private and family life), Article 9 (right to freedom of thought, conscience and religion), Article 10 (freedom of expression), Article 11 (freedom of assembly and association), Article 14 (prohibition of discrimination in the enjoyment of ECHR rights), Article 4 of Protocol No.4 (collective expulsion of aliens), Article 1 of Protocol No.7 (exclusion of own nationals), Article 4 of Protocol No.7 (prohibition of double jeopardy) and Article 1 of Protocol No.12 (general prohibition on discrimination) (Mole and Meredith, 2010: 23).

\section{The Principle of Non-Refoulement under the ECHR}

When it recognized the applicability of the ECHR to asylum cases through interpretation of Article 3, the ECtHR has actually at the same time recognized and established the principle of non-refoulement under the ECHR. Namely, this principle was discussed for the first time in the case of Soering $v$. the United Kingdom, in the context of the applicability of the ECHR to asylum cases (concretely, the applicability to extradition or removal) through interpretation of Article 3: "... [T]he decision by a Contracting State to extradite a fugitive may give rise to an issue under Article 3 ... where substantial grounds have been shown for believing that 
the person concerned, if extradited, faces a real risk of being subjected to torture or to inhuman or degrading treatment or punishment in the requesting country" (Soering v. the United Kingdom, 991). In this sense, it could be noted that even if there is no specific mention to the principle of nonrefoulement in Article 3, the ECtHR has interpreted this Article to include the prohibition of refoulement (Bacian, 2011: 40).

The fact that the principle of non-refoulement under the ECHR, unlike the Refugee Convention, extends to inhuman and degrading behavior (Röhl, 2005: 1), makes the ECHR "one of the most important juridical instruments for protection of asylum seekers throughout Europe" (Bacian, 2011: 54). Namely, the prohibition of refoulement is "a form of complementary protection covering a wider category of 'refugees' beyond the 1951 definiton" (Maas, 2009: 16). According to McAdam, complementary protection describes "the role of human rights in broadening the categories of persons to whom international protection is owed beyond Article 1A(2) of the Refugee Convention" (McAdam in Maas, 2009: 16).

The implicit non-refoulement obligation, emanating from Article 3 of the ECHR, was the main source of complementary protection of asylum seekers in EU Member States until 2004, when the Qualification Directive 2004/83/EC was adopted (Maas, 2009: 16). The Qualification Directive 2004/83/EC (later revised with the Qualification Directive 2011/95/EU) codifies in large part the jurisprudence on complementary protection under Article 3 of the ECHR (Maas, 2009: 19). Before the adoption of the Qualification Directive 2004/83/EC, specific international law on complementary protection did not exist (Maas, 2009: 16). In the Qualification Directive 2004/83/EC, complementary protection is referred to as "subsidiary protection" (Maas, 2009: 18). This Directive defines the criteria of eligibility for subsidiary protection and codifies the prohibition of refoulement (Maas, 2009: 18-19).

\section{Comparison of EU law and ECHR protection standards for asylum seekers}

Regarding the protection standards for asylum seekers under EU law, the EU has an obligation to provide a policy for asylum, subsidiary protection and temporary protection, which is foreseen in Article 78 of the Treaty on the Functioning of the EU. In this sense, the EU is obliged to ensure compliance with the principle of non-refoulement and this policy must be in accordance with the ECHR, the Refugee Convention, the UNCAT, the ICCPR and other relevant treaties. The EU asylum acquis measures, which have been adopted under this policy, include the Dublin Regulation (Regulation (EU) No.604/2013, the Qualification Directive (2011/95/EU), the Asylum Procedures Directive (2013/32/EU) and the 
Reception Conditions Directive (2013/33/EU) (European Union Agency for Fundamental Rights and Council of Europe, 2014: 64-65).

The Qualification Directive (2011/95/EU) introduces "a set of common standards for the qualification of persons as refugees or those in need of international protection" into EU law. It includes the rights and duties of that protection, where the key element is non-refoulement under Article 33 of the Refugee Convention (European Union Agency for Fundamental Rights and Council of Europe, 2014: 65).

The Qualification Directive 2011/95/EU provides "subsidiary protection" for persons who do not qualify as refugees, but if they are returned to their country of origin or former habitual residence, they would face a real risk of suffering serious harm defined as" the death penalty or execution" (Article 15(1)), "torture or inhuman or degrading treatment or punishment" (Article 15(b)) and "serious and individual threat to a civilian's life or person by reason of indiscriminate violence in situations of international or internal armed conflict" (Article 15(c)) (Qualification Directive 2011/95/EU).

The prohibition of refoulement is explicitly codified in Article 21(1) of the Qualification Directive 2011/95/EU, according to which "Member States shall respect the principle of non-refoulement in accordance with their international obligations". This article reaffirms the obligation of Member States to respect the principle of non-refoulement, but it also foresees a few exceptions to this rule within its second paragraph (Qualification Directive 2011/95/EU). Similarly, Article 17 of the Qualification Directive 2011/95/EU foresees several exceptions under which a third-country national or a stateless person could be excluded from being eligible for subsidiary protection (Qualification Directive 2011/95/EU).

It could be noted that neither Article 33 of the Refugee Convention nor Articles 17 and 21 of the Qualification Directive 2011/95/EU contain absolute prohibition of refoulement. Namely, these articles "allow for the removal of a refugee in very exceptional circumstances", such as when the person has committed a serious crime or when the person constitutes a danger to the community or to the security of the Member State in which that person is present (European Union Agency for Fundamental Rights and Council of Europe, 2014: 65).

As to the protection standards under the ECHR, Article 3 absolutely prohibits any return of an individual who would face a real risk of treatment contrary to this provision, which is different from the risk of persecution on one of the grounds foreseen in the Refugee Convention (European Union Agency for Fundamental Rights and Council of Europe, 2014: 66). Namely, the formulation of Article 3 does not allow for any exceptions, not even for reasons of public interest nor for national security. Moreover, no derogations 
are allowed as regards Article 3 in times of war or due to public emergency (Maas, 2009: 28).

Article 3 prohibits torture or inhuman or degrading treatment or punishment in absolute terms, irrespective of the victims conduct. Under Article 3, the responsibility of the state will be engaged "when any expulsion is made where substantial grounds have been shown for believing that the person concerned faced a real risk of being subjected to torture or to human or degrading treatment or punishment in the country to which he or she was returned" (European Union Agency for Fundamental Rights and Council of Europe, 2014: 66; Salah Sheekh v. the Netherlands, ๆ135).

The absolute nature of Article 3 has been confirmed by the ECtHR many times. In this sense, in the case of Saadi v. Italy, the ECtHR noted that "states face immense difficulties in modern times in protecting their communities from terrorist violence". Nevertheless, the ECtHR concluded that "must not, however, call into question the absolute nature of Article 3" (Saadi v. Italy, 9137). Futher, the ECtHR reaffirmed that "... it is not possible to weigh the risk of ill-treatment against the reasons put forward for the expulsion in order to determine whether the responsibility of a State is engaged under Article $3 \ldots$ In that connection, the conduct of the person concerned, however undesirable or dangerous, cannot be taken into account, with the consequence that the protection afforded by Article 3 is broader than that provided for in Articles 32 and 33 of the 1951 United Nations Convention relating to the Status of Refugees" (Saadi v. Italy, 1138).

Having in mind the foregoing, It could be noted that although the regime established under the CEAS fills some of the gaps regarding those individuals who need international protection, but do not fall within the scope of the Refugee Convention, it "still fails to apply to all those who are recognized by the European Court of Human Rights as being in need of - and entitled to - international protection" (Mole and Meredith, 2010: 11).

\section{Conclusion}

The definition of a refugee under the Refugee Convention does not cover all individuals who seek international protection. This is mainly due to the lack of possibility to establish a link between the persecution feared and one of the five grounds that the Refugee Convention foresees (race, religion, nationality, membership of a particular social group or political opinion). However, the EU Member States have managed to fill this gap by introducing complementary protection, based on the jurisprudence of the ECtHR. Namely, the ECtHR has interpreted Article 3 of the ECHR in the sense to impose prohibition to remove an individual if substantial grounds have been shown that he or she will suffer treatment contrary to Article 3, such as torture or inhuman and degrading treatment or punishment. 
It could be concluded that this implicit obligation of non-refoulement, emanating from Article 3, represents a barrier to removal that provides significant complementary protection to refugees from expulsion. The significant complementary role that the principle of non-refoulement under the ECHR plays regarding the protection of asylum seekers is even more strengthened by the absolute character of non-refoulement under Article 3. Namely, the principle of non-refoulement under Article 3 of the ECHR has an absolute character, unlike the prohibition of refoulement later codified under EU law, which is not absolute and provides grounds for exceptions to the prohibition.

The complementary protection provided by the prohibition of refoulement under the ECHR is not formally codified, while this is not the case in terms of EU law anymore. Namely, the Qualification Directive 2004/83/EC (later revised with the Qualification Directive 2011/95/EU), which refers to complementary protection as subsidiary protection, has in large part codified the jurisprudence on complementary protection under Article 3. It defines the criteria of eligibility for subsidiary protection and codifies the prohibition of non-refoulement.

Having in consideration the previous, it could be concluded that the jurisprudence of the ECtHR has important relevance to the EU asylum law and policy. However, based on the comparison of EU law and ECHR protection standards for asylum seekers, it could also be concluded that there are differences between EU law protection standards for asylum seekers and those of the ECHR. This is particularly the case in terms of non-refoulement obligations under Article 3 of the ECHR and subsidiary protection foreseen in the Qualification Directive 2011/95/EU, as supranational EU Law.

Yet, one should have in mind that the two regimes are independent and that the ECHR binds the EU Member States, not the EU itself. However, EU Member States are bound under both regimes. As a consequence, EU Member States are faced with dual systems providing protection to those who seek asylum. This could lead to different rulings as regards similar issues of protection, and a number of complexities and uncertainties. A possible step forward towards getting out of this situation, and avoiding the various problems that inevitably arise when dual systems exist at the same time, could be acceleration and completion of the process of EU accession to the ECHR, provided for by the Treaty of Lisbon and Protocol 14 to the ECHR.

\section{References:}

1. Bacaian, L.E. (2011). The Protection of Refugees and Their Right to Seek Asylum in the European Union. Institut Europèen de 
l'Universitè de Genève, Collection Europa, Master Thesis, Vol.702011

2. Chapman, A.R. (1999). A Human Rights Perspective on Intellectual Property, Scientific Progress and Access to the Benefits of Science. In WIPO Publication No.762(E), Intellectual Property and Human Rights. Geneva: WIPO Publication

3. Council of Europe. (1950). Convention for the Protection of Human Rights and Fundamental Freedoms, as amended by Protocols Nos.11 and 14, supplemented by Protocols 1, 4, 6, 7, 12 and 13, European Treaty Series, No.5

4. European Council. (2004). Directive 2004/83/EC of the Council on Minimum Standards for the Qualification and Status of Third Country Nationals or Stateless Persons as Refugees or as Persons Who Otherwise Need International Protection and the Content of the Protection Granted, Official Journal of the European Union, L 304/12

5. European Court of Human Rights. (1991). Cruz Varas v. Sweden, Application No.15576/89

6. European Court of Human Rights. (1999). Lilia, Julia and Eleonora Alimzhanova and Alexijs Lisikov v. Sweden, Application No.38821/97

7. European Court of Human Rights. (2008). Saadi v. Italy, Application No.37201/06

8. European Court of Human Rights. (2007). Salah Sheekh v. the Netherlands, Application No.1948/04

9. European Court of Human Rights. (1989). Soering v. the United Kingdom, Application No.14038/88

10. European Court of Human Rights. (1991). Vilvarajah and others $v$. the United Kingdom, Application Nos.13163/87, 13164/87, 13165/87, 13447/87 and 13448/87

11. European Parliament and European Council. (2011). Directive 2011/95/EU of the European Parliament and of the Council on Standards for the Qualifications of Third-Country Nationals or Stateless Persons as Beneficiaries of International Protection, for a Uniform Status of Refugees or for Persons Eligible for Subsidiary Protection, and for the Content of the Protection Granted, Official Journal of the European Union, L 337/9

12. European Union Agency for Fundamental Rights and Council of Europe. (2014). Handbook on European Law Relating to Asylum, Borders and Immigration, Luxemburg: Publication Office of the European Union 
13. Maas, S. (2009). Dual Protection in European Asylum Law: Good or Bad for those Seeking Subsidiary Protection. Thesis L.L.M. European Law 2008-2009

14. Mole, N. \& Meredith, C. (2010). Asylum and the European Convention on Human Rights, Human Rights Files No.9, Strasbourg: Council of Europe Publishing

15. Röhl, K. (2005). Fleeing Violence and Poverty: Non-Refoulemenet Obligations under the European Convention on Human Rights, Working Paper No.111, Geneva: UNHCR

16. UNHCR. (2011). Handbook and Guidelines on Procedures and Criteria for Determining Refugee Status, Geneva: UNHCR

17. United Nations. (1951). Convention relating to the Status of Refugees, United Nations, Treaty Series, Vol. 189 